\title{
Neurotrophin-3 Contributes to the Initiation of Behavioral Sensitization to Cocaine by Activating the Ras/Mitogen-Activated Protein Kinase Signal Transduction Cascade
}

\author{
R. Christopher Pierce, ${ }^{1}$ Audrey F. Pierce-Bancroft, ${ }^{1}$ and Balakrishna M. Prasad ${ }^{2}$ \\ 1Laboratory of Neuropsychopharmacology, Departments of Pharmacology and Psychiatry, Boston University School of \\ Medicine, Boston, Massachusetts 02118, and ${ }^{2 H o w a r d ~ H u g h e s ~ M e d i c a l ~ I n s t i t u t e ~ a n d ~ V o l l u m ~ I n s t i t u t e ~ f o r ~ A d v a n c e d ~}$ \\ Biomedical Research, Portland, Oregon 97201
}

\begin{abstract}
These experiments were designed to assess the role of neurotrophins and the Ras/mitogen-activated protein kinase (MAP) signal transduction cascade in behavioral sensitization to cocaine. The first experiments evaluated the effect of three daily intra-ventral tegmental area (VTA) microinjections of neurotrophin-3 (NT-3) or brain-derived neurotrophic factor (BDNF) on the behavioral-activating effects of a subsequent challenge injection of cocaine in rats. Results indicated that, although NT-3 did not influence behavior across the three microinjection days, animals displayed a sensitized behavioral response to the subsequent cocaine challenge injection. In contrast, BDNF microinjections resulted in a progressive increase in behavioral activity but did not influence the subsequent behavioral response to cocaine. A second series of experiments assessed the effect of inhibiting the MAP kinase signal transduction cascade on the initiation of behavioral sensitization to cocaine. The MAP kinase kinase inhibitor PD98059,
\end{abstract}

Research focusing on the identification of the physiological modifications underlying the sensitized behavioral response to repeated daily injections of cocaine has centered mainly on the mesolimbic dopamine system (Kalivas and Stewart, 1991; Robinson and Berridge, 1993; Pierce and Kalivas, 1997). The neurotrophins, which play an important role in several forms of neuroplasticity (Davies, 1994; Thoenen, 1995), are expressed by dopamine neurons in the ventral midbrain. The members of the nerve growth factor (NGF) family of neurotrophins that are active in the mammalian brain include NGF, brain-derived neurotrophic factor (BDNF), neurotrophin-3 (NT-3), and neurotrophin-4/5 (NT-4/5) (Davies, 1994; Bothwell, 1995; Lewin and Barde, 1996). Dopamine cells of the ventral midbrain express mRNA for BDNF and NT-3 (Gall et al., 1992; Seroogy et al., 1994); these neurotrophins support the survival of dopaminergic neurons (Hyman et al., 1991; Knusel et al., 1991) and protect dopaminergic cells from certain neurotoxins (Hyman et al., 1991;

\footnotetext{
Received April 8, 1999; revised June 17, 1999; accepted June 20, 1999.

This work was supported by National Institutes of Health Grant DA11168 and a National Alliance for Research on Schizophrenia and Depression Young Investigator Award. We thank Stephanie Licata for assistance with the PD98059 experiment, as well as Drs. Peter Kalivas and Behnam Ghasemzadeh for their advice and encouragement.

Correspondences should be addressed to Chris Pierce, Department of Pharmacology, R-612, Boston University School of Medicine, 715 Albany Street, Boston, MA 02118.

For information on the Laboratory of Neuropsychopharmacology at the Boston University School of Medicine, see http://med-pharm53.bu.edu/pages/pierce.html. Copyright (C) 1999 Society for Neuroscience $0270-6474 / 99 / 198685-11 \$ 05.00 / 0$
}

or its vehicle, was microinjected into the VTA before three daily cocaine injections. Although PD98059 did not influence the acute behavioral response to cocaine, it blocked sensitization. Finally, the effects of acute and repeated cocaine injections on NT-3 and BDNF mRNA levels in the VTA, substantia nigra, and hippocampus were assessed. Results indicated that an acute cocaine injection resulted in a transient increase in NT-3 mRNA levels in the VTA. Collectively, these results suggest that NT-3 contributes to the initiation of behavioral sensitization to cocaine by activating the Ras/MAP kinase signal transduction system. The present data also indicate that BDNF itself produced a progressive augmentation in behavioral activation with repeated administration.

Key words: behavioral sensitization; brain derived neurotrophic factor (BDNF); cocaine; mitogen-activated protein (MAP) kinase; neurotrophin-3 (NT-3); neurotrophins; substantia nigra; ventral tegmental area (VTA)

Beck et al., 1992; Spina et al., 1992). NGF is expressed at low levels in the ventral midbrain (Spillantini et al., 1989; Ceccatelli et al., 1991; Lauterborn et al., 1991, 1995) and has no discernible influence on dopamine cells (Hyman et al., 1991; Knusel et al., 1991; Spina et al., 1992), whereas NT-4/5 expression in the CNS is very low (Timmusk et al., 1993). Collectively, these data indicate that dopaminergic neurons in the ventral midbrain synthesize BDNF and NT-3 but not NGF or NT-4/5.

Midbrain dopaminergic neurons also express tyrosine kinase B (TrkB) and TrkC receptors, which, when activated by BDNF or NT-3, respectively, stimulate signal transduction cascades, including the Ras/mitogen-activated protein (MAP) kinase system (Seger and Krebs, 1995; Lewin and Barde, 1996; Numan and Seroogy, 1999). The phosphorylated Trk receptor serves as a scaffolding for effector molecules that contain the Src homology 2 domain, such as Shc, which becomes a substrate through which Grb2 and the Ras guanine triphosphate exchange factor, Sos, associate with the Trk receptor. The Trk-Shc-Grb2-Sos complex activates the G-protein Ras, which stimulates the MAP kinase signal transduction cascade (Seger and Krebs, 1995; Lewin and Barde, 1996). Ras activates a MAP 3kinase (Raf kinase), which phosphorylates and activates a MAP kinase kinase [MAP kinase/ERK kinase (MEK)], which in turn phosphorylates the MAP kinases [extracellular signal-regulated kinases (ERKs)] (Seger and Krebs, 1995; Lewin and Barde, 1996). When activated by MEK, the ERKs become proline-directed, phosphorylating serine or threonine residues that neighbor prolines. Thus, there 
Table 1. Protocols for the behavioral experiments

\begin{tabular}{|c|c|c|c|}
\hline Day 1 & Days $2-4$ & $\begin{array}{l}\text { Day } 5 \\
\text { (early withdrawal) }\end{array}$ & $\begin{array}{l}\text { Day } 18 \\
\text { (late withdrawal) }\end{array}$ \\
\hline \multicolumn{4}{|c|}{ Neurotrophin-cocaine cross-sensitization } \\
\hline Sham microinjection & $\begin{array}{r}\text { Neurotrophin microinjection } \\
\text { (VTA or substantia nigra) }\end{array}$ & $\begin{array}{l}\text { Cocaine } \\
(15 \mathrm{mg} / \mathrm{kg} \text {, i.p. })\end{array}$ & $\begin{array}{l}\text { Cocaine } \\
(15 \mathrm{mg} / \mathrm{kg} \text {, i.p.) }\end{array}$ \\
\hline Sham microinjection & $\begin{array}{l}\text { Vehicle microinjection } \\
\text { (VTA or substantia nigra) }\end{array}$ & $\begin{array}{l}\text { Cocaine } \\
(15 \mathrm{mg} / \mathrm{kg} \text {, i.p. })\end{array}$ & $\begin{array}{l}\text { Cocaine } \\
(15 \mathrm{mg} / \mathrm{kg} \text {, i.p.) }\end{array}$ \\
\hline \multicolumn{4}{|c|}{ Effect of PD98059 on cocaine sensitization } \\
\hline Sham/saline injection & $\begin{array}{l}\text { Intra-VTA PD } 98059 \text { plus cocaine } \\
\quad(15 \mathrm{mg} / \mathrm{kg} \text {, i.p. })\end{array}$ & & $\begin{array}{l}\text { Cocaine } \\
(15 \mathrm{mg} / \mathrm{kg} \text {, i.p. })\end{array}$ \\
\hline Sham/saline injection & $\begin{array}{l}\text { Intra-VTA vehicle plus cocaine } \\
\quad(15 \mathrm{mg} / \mathrm{kg} \text {, i.p. })\end{array}$ & & $\begin{array}{l}\text { Cocaine } \\
(15 \mathrm{mg} / \mathrm{kg} \text {, i.p.) }\end{array}$ \\
\hline
\end{tabular}

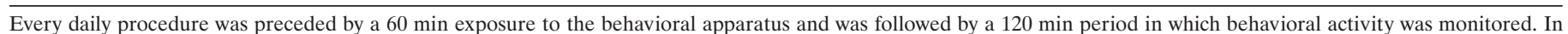

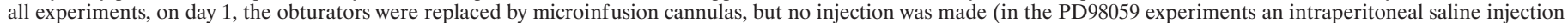

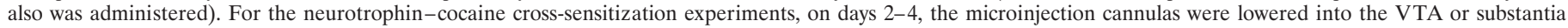

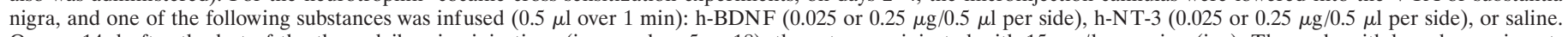

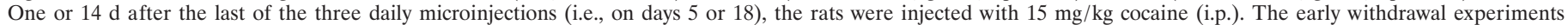

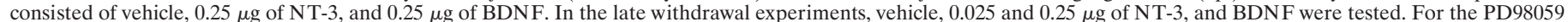

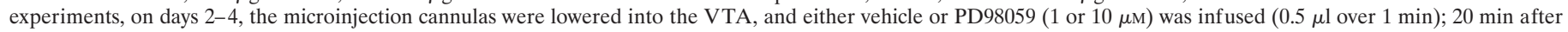

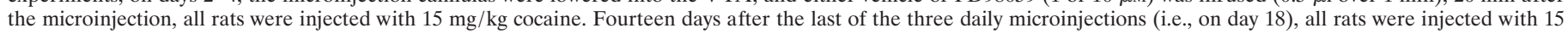
$\mathrm{mg} / \mathrm{kg}$ cocaine (i.p.).

are many substrates for the ERKs in both the cytoplasm and nucleus, including tyrosine hydroxylase, the rate-limiting enzyme in catecholamine synthesis (Haycock et al., 1992; Seger and Krebs, 1995).

Cocaine sensitization is associated with changes in the MAP kinase signal transduction cascade (Berhow et al., 1995, 1996). After 10 twice daily injections of cocaine, but not after acute administration, there is a significant increase in ERK activity in the ventral tegmental area (VTA) (Berhow et al., 1996). Subsequent experiments revealed that repeated cocaine injections had no influence on ERK immunoreactivity in the VTA, suggesting that there is a higher phosphorylation state of this enzyme after repeated cocaine (Berhow et al., 1996). The current experiments, designed to further assess the role of neurotrophins and the Ras/MAP kinase signal transduction cascade in behavioral sensitization to cocaine, were conducted as follows: (1) the effects of repeated intra-VTA microinjections of BDNF or NT-3 on the behavioral response to a subsequent challenge injection of cocaine were assessed; (2) the influence of an MEK inhibitor, PD98059, on the initiation of behavioral sensitization to cocaine was evaluated; and (3) the effects of acute and repeated cocaine injections on neurotrophin mRNA levels in the mesolimbic dopamine system were determined.

\section{MATERIALS AND METHODS}

Animal housing. Male Sprague Dawley rats weighing 250-300 gm were obtained from Taconic Farms (Germantown, NY). Animals were individually housed with food and water available ad libitum. A $12 \mathrm{hr}$ light/dark cycle was used with the lights on at 6:00 A.M. All experimental procedures were performed during the light cycle.

Experimental design for the behavioral experiments. The protocols for the behavior experiments, which are summarized in Table 1, are based on previous results indicating that repeated daily microinjections of amphetamine (Perugini and Vezina, 1994; Bjijou et al., 1996; Vezina, 1996) or SKF-38393 (Pierce et al., 1996) into the VTA/substantia nigra result in a sensitized behavioral response to a subsequent systemic injection of a psychostimulant. In some of the present behavioral experiments, a $14 \mathrm{~d}$ withdrawal period was imposed between the repeated microinjections and the cocaine challenge injection. The use of a withdrawal period is based on previous research in which the insertion of 14 or more days of withdrawal between the repeated drug treatment and a subsequent psychostimulant challenge injection resulted in a more robust sensitization of the behavioral response (Kolta et al., 1985; Kalivas and Duffy, 1993a; Paulson and Robinson, 1995).

Effect of intra-VTA/substantia nigra BDNF or NT-3 on the subsequent behavioral response to cocaine. Before surgery, the rats were anesthetized with pentobarbital $(50 \mathrm{mg} / \mathrm{kg})$ and mounted in a stereotaxic apparatus. Cannulas (12 mm, 26 gauge) were implanted bilaterally $1 \mathrm{~mm}$ dorsal to the VTA or substantia nigra and cemented in place by affixing dental acrylic to three stainless steel screws tapped into the skull. After surgery, all animals were allowed to recover for $3-5 \mathrm{~d}$. The coordinates for the VTA and substantia nigra [relative to bregma according to the atlas of Paxinos and Watson (1997)] were as follows: -5.0 anteroposterior (AP), \pm 0.5 mediolateral (ML), -7.0 dorsoventral (DV) (VTA); $-5.0 \mathrm{AP}, \pm 2.0$ ML, -7.0 DV (substantia nigra).

After recovery from surgery, all animals initially were habituated to the behavioral testing arena for $3 \mathrm{hr}$. Before each microinjection, the rats were rehabituated to the photocell apparatus (AccuScan Instruments, Columbus, $\mathrm{OH}$ ) for $1 \mathrm{hr}$. The obturators then were removed from the microinjection guide cannulas and replaced by injection needles (33 gauge stainless steel), which extended $1 \mathrm{~mm}$ below the end of the guide cannulas into the VTA. Bilateral infusions of BDNF or NT-3 (0.025 or $0.25 \mu \mathrm{g}$ ) or sterile $0.9 \%$ saline were made over $60 \mathrm{sec}$ in a volume of 0.5 $\mu \mathrm{l} / \mathrm{side}$. The guide cannulas were left in place for $30 \mathrm{sec}$ (to allow the compound to diffuse away from the tips of the cannulas) and then removed. After the microinjection, each rat was returned to its testing chamber immediately, and behavior was monitored for $2 \mathrm{hr}$. These neurotrophin or saline microinjections were made once daily for 3 consecutive days. One day or 2 weeks after the last of the three microinjections, the animals were rehabituated to the behavioral chambers for $1 \mathrm{hr}$, followed by an intraperitoneal injection of $15 \mathrm{mg} / \mathrm{kg}$ cocaine. Behavioral activity was monitored for $2 \mathrm{hr}$ after the cocaine injection.

An additional experiment assessed the effect of three microinjections of NT-3 $(0.25 \mu \mathrm{g} / 0.5 \mu \mathrm{l}$ per side $)$ into the substantia nigra on the behavioral response to cocaine after $14 \mathrm{~d}$ of withdrawal. The procedures were identical to those described above, except the saline and NT-3 microinjections were made into the substantia nigra.

Effect of intra-VTA PD98059 on the initiation of behavioral sensitization to cocaine. The surgical procedures were the same as those described above. All animals initially were habituated to the behavioral testing arena for $3 \mathrm{hr}$. Before each daily microinjection, the rats were rehabituated to the photocell apparatus for $1 \mathrm{hr}$. The obturators then were removed from the microinjection guide cannulas and replaced by injection needles (33 gauge stainless steel), which extended $1 \mathrm{~mm}$ below the end of the guide cannulas into the VTA. Bilateral infusions of PD98059 (1 or $10 \mu \mathrm{M}$ ) or vehicle (saline or 100\% DMSO) were made over $60 \mathrm{sec}$ in a volume of $0.5 \mu \mathrm{l} / \mathrm{side}$. The guide cannulas were left in place for 30 sec (to allow the compound to diff use away from the tips of the cannulas) 
and then removed. After the microinjection, the rats were returned to the testing chambers. Twenty minutes after the microinjection, all animals received an intraperitoneal injection of $15 \mathrm{mg} / \mathrm{kg}$ cocaine. Behavior was monitored for $2 \mathrm{hr}$ after the cocaine injection. The combination of intra-VTA microinjections and intraperitoneal cocaine injections were made once daily for 3 consecutive days. Two weeks after the last of the three daily treatments, the animals were rehabituated to the behavioral chambers for $1 \mathrm{hr}$, followed by an intraperitoneal injection of $15 \mathrm{mg} / \mathrm{kg}$ cocaine; behavioral activity then was monitored for $2 \mathrm{hr}$.

The AccuScan activity monitors generate several measures of motor activity. For the purposes of this study, we present measures of locomotion and stereotyped behaviors. Using the AccuScan system, the most accurate measure of locomotion is distance travelled, which is expressed in centimeters. Rodents administered psychostimulants also display a number of repetitive behaviors, including head bobbing and grooming. These behaviors are quantified as stereotypy counts, which the AccuScan system defines as the animal breaking the same photocell beam or set of beams repeatedly. Previous experiments were performed to ensure a strong positive correlation between the cocaine-induced locomotion and stereotypy ratings made by experienced human observers and those obtained with the photocell-based AccuScan activity monitors (Pierce and Kalivas, 1998).

After the completion of the microinjection experiments, the rats were overdosed with pentobarbital $(>100 \mathrm{mg} / \mathrm{kg}$, i.p.) and perfused intracardially with $0.9 \%$ saline, followed by $10 \%$ formalin. The brain was removed, and coronal sections $(100 \mu \mathrm{m})$ were taken at the level of the VTA/substantia nigra with a Vibratome (Technical Products International, St. Louis, MO). The sections were mounted on gelatin-coated slides and stained with cresyl violet. Probe and cannula placements were determined by an individual unaware of the rats' behavioral response.

Effect of acute and repeated cocaine on BDNF and NT-3 mRNA levels in the VTA, substantia nigra, and hippocampus. Animals in the acute groups were injected with $30 \mathrm{mg} / \mathrm{kg}$ (i.p.) cocaine or saline and then killed by rapid decapitation $2,4,6$, or $24 \mathrm{hr}$ after the injection. In the repeated treatment groups, rats were injected intraperitoneally with cocaine (30 $\mathrm{mg} / \mathrm{kg}$ ) or saline once daily for 7 consecutive days in the home cage; on the eighth day, the animals were injected with either $30 \mathrm{mg} / \mathrm{kg}$ cocaine or saline and then killed by rapid decapitation $4 \mathrm{hr}$ after injection. In all cases, the brain was removed and placed on dry ice, and the VTA, substantia nigra, and hippocampus were excised and stored at $-80^{\circ} \mathrm{C}$. Total tissue RNA was extracted with phenol and chloroform and precipitated with ethanol (Cathala et al., 1983). First-strand cDNA was synthesized with the use of $200 \mathrm{ng}$ of hexanucleotide random primer (Boehringer Mannheim, Indianapolis, IN) and 200 U of Superscript II reverse transcriptase (Life Technologies, Gaithersburg, MD) according to the manufacturer's protocol.

For PCR, each tube contained $5 \mu$ l of $10 \times$ PCR buffer (Fisher Scientific, Pittsburgh, PA), 2.5 U of AmpliTaq DNA polymerase (Fisher Scientific), $1 \mu \mathrm{M}$ of each primer, $1 \mu \mathrm{M}$ of each control primer (cyclophilin), $0.2 \mathrm{~mm}$ dNTPs, $2.5 \mathrm{mM} \mathrm{MgCl}$, and $1 \mu \mathrm{l}$ of the first-strand cDNA in a final volume of $50 \mu \mathrm{l}$. All primers were custom synthesized by Life Technologies based on unique sequences obtained from GenBank and verified by the National Center for Biotechnical Information BLAST program. The primers were as follows: BDNF sense, CTT GGA CAG AGC CAG CGG ATT TGT (bases 4-27; GenBank accession number M61175); BDNF antisense, GTC CTC ATC CAG CAG CTC TTC GAT (bases 277-300; accession number M61175); NT-3 sense, GGA TGC CAT GGT TAC TTC TGC CAC (bases 27-50; accession number M34643); NT-3 antisense, GGG CAG GGT GCT CTG GTA ATT TTC (bases 241-264; accession number M34643); cyclophilin sense, GTC TGC TTC GAG CTG TTT GCA GAC (bases 99-122; accession number M19533); and cyclophilin antisense, CCA CAG TCG GAG ATG GTG ATC TTC (bases 503-526; accession number M19533).

Hot-start PCR was used with $\mathrm{MgCl}_{2}$ added after an initial denaturation step of $95^{\circ} \mathrm{C}$ for $4 \mathrm{~min}$. The PCR conditions were: $94^{\circ} \mathrm{C}$ for $1.5 \mathrm{~min}$, $63^{\circ} \mathrm{C}$ for $1 \mathrm{~min}$, and $72^{\circ} \mathrm{C}$ for $1 \mathrm{~min}$. All samples underwent a final extension time of $10 \mathrm{~min}$ at $72^{\circ} \mathrm{C}$. Reverse transcription (RT) product from the VTA or substantia nigra underwent 33 cycles; cyclophilin was added after the eighth cycle. RT product from the hippocampus underwent 28 cycles; cyclophilin was added after the fifth cycle. Aliquots of the PCR product $(19 \mu \mathrm{l})$ were separated with electrophoresis on a $2 \%$ agarose gel containing ethidium bromide $(0.5 \mu \mathrm{g} / \mathrm{ml})$. The bands were visualized with UV light, and the band intensities were measured using computerized densitometry.
Preliminary experiments confirmed that the quantity of RT product, the $\mathrm{MgCl}_{2}$ concentration, and the number of cycles chosen were in the linear range. Because tissue RNA samples may contain DNA contamination that could result in non-RNA-derived reaction products, preliminary PCR experiments were conducted without the RT step. No amplified fragments were observed in these experiments.

As reviewed above, dopamine cells of the ventral midbrain express mRNA for BDNF and NT-3 (Gall et al., 1992; Seroogy et al., 1994) but not NGF (Ceccatelli et al., 1991; Lauterborn et al., 1991). The main targets of the mesencephalic dopamine neurons (i.e., the nucleus accumbens and neostriatum) do not express appreciable levels of the mRNA for BDNF or NT-3 (Ernfors et al., 1990; Lauterborn et al., 1991; Conner et al., 1997), whereas the hippocampus, which also receives dopaminergic afferents, expresses high levels of BDNF and NT-3 mRNA (Ernfors et al., 1990; Ceccatelli et al., 1991; Conner et al., 1997). Based on these findings, our RT-PCR experiments focused on the VTA, substantia nigra, and hippocampus.

Drugs. h-BDNF and h-NT-3, synthesized from recombinant Escherichia coli, were obtained from Alomone Labs (Jerusalem, Israel). PD98059, a synthetic inhibitor of MEK that has no significant effect on MAP kinase itself (Dudley et al., 1995), was obtained from Calbiochem (La Jolla, CA). Cocaine was a gift from the National Institute on Drug Abuse (Rockville, MD). h-BDNF, h-NT-3, and cocaine were dissolved in sterile $0.9 \% \mathrm{NaCl}$. PD98059 is soluble in DMSO.

\section{RESULTS}

\section{Repeated microinjections of NT-3 into the VTA produce a sensitized behavioral response to a challenge injection of cocaine after $14 \mathrm{~d}$ of withdrawal}

The data summarized in Figure $1 A$ indicate that the distance travelled after cocaine was significantly greater in the group that received three repeated microinjections of $0.25 \mu \mathrm{g} \mathrm{NT}-3$ than the saline control group. The data collected on each treatment day were analyzed with separate one-way ANOVAs. The analysis of the distance travelled data depicted in Figure $1 A$ revealed a marginally significant main effect of drug treatment on day 18 $\left(F_{(2,16)}=2.49 ; p<0.11\right)$. However, pairwise comparisons (Fisher's LSD) revealed a significant difference between the saline and $0.25 \mu \mathrm{g}$ NT-3 groups on day 18. The time course data presented in Figure $1 B$ were analyzed with a mixed factors ANOVA (repeated measure over time). This analysis revealed significant main effects of drug treatment $\left(F_{(1,99)}=20.69 ; p<0.0014\right)$, time $\left(F_{(11,99)}=19.96 ; p<0.0001\right)$, and a significant drug $\times$ time interaction $\left(F_{(11,99)}=2.77 ; p<0.0036\right)$. Pairwise comparisons (Fisher's LSD) revealed a significant difference between the NT-3 and saline groups at the 30 and 40 min time points.

The stereotypy data (Fig. $1 C, D$ ) were analyzed using the same statistics as the distance travelled data summarized above. The analysis of the data shown in Figure $1 C$ revealed no significant drug treatment effects on any of the treatment days. Analysis of the time course data from day 18 (Fig. 1D) revealed significant main effects of drug treatment $\left(F_{(1,99)}=7.19 ; p<0.025\right)$ and time $\left(F_{(11,99)}=15.64 ; p<0.0001\right)$. Pairwise comparisons (Fisher's LSD) demonstrated a significant difference between the NT-3 and saline groups at the 30 and 40 min time points.

The effect of $0.25 \mu \mathrm{g} / 0.5 \mu \mathrm{l} \mathrm{NT}-3$ microinjections into the substantia nigra on the behavioral response to cocaine after $14 \mathrm{~d}$ of withdrawal also was evaluated. The results indicate that there was no difference in the behavioral response to cocaine between the rats previously microinjected with NT-3 or saline in the substantia nigra (data not shown). Analysis of the time course data from day 18 revealed only a significant main effect of time $\left(F_{(11,33)}=33.0 ; p<0.0001\right)$. 
Figure 1. Repeated microinjections of NT-3 into the VTA produce a sensitized behavioral response to a subsequent challenge injection of cocaine after $14 \mathrm{~d}$ of withdrawal. On days $2-4$, the animals were microinjected with sterile saline or NT-3 $(0.025$ or $0.25 \mu \mathrm{g} / 0.5 \mu \mathrm{l}$ per side). After a 2 week withdrawal period (i.e., on day 18), all animals were injected with cocaine $(15 \mathrm{mg} / \mathrm{kg}$, i.p.). $A$, The total distance travelled (in centimeters) recorded over the $120 \mathrm{~min}$ period after the intra-VTA microinjection or the systemic injection of cocaine. Note that the behavioral effect of cocaine on day 18 was significantly greater in the $0.25 \mu \mathrm{g}$ NT-3 group than the saline group. $B$, Time course of the distance travelled after cocaine in the $0.25 \mu \mathrm{g} \mathrm{NT}-3$ and saline groups from day 18 in $A$. The data are presented as the $120 \mathrm{~min}$ behavioral response (distance travelled) divided into $10 \mathrm{~min}$ blocks. Note that the behavioral effect of cocaine on day 18 in the $0.25 \mu \mathrm{g}$ NT-3 group was significantly greater than the saline group 30 and $40 \mathrm{~min}$ after injection. $C$, The stereotypy counts recorded over the $120 \mathrm{~min}$ period after the intra-VTA microinjection or the systemic injection of cocaine. Note that the behavioral effect of cocaine on day 18 was substantially greater in the $0.25 \mu \mathrm{g} \mathrm{NT-3}$ group relative to the saline group. $D$, Time course of the stereotypy counts after cocaine in the $0.25 \mu \mathrm{g}$ NT-3 and saline groups from day 18 in $C$. The data are presented as the $120 \mathrm{~min}$ behavioral response (stereotypy counts) divided into $10 \mathrm{~min}$ blocks. Note that the behavioral effect of cocaine on day 18 in the $0.25 \mu \mathrm{g} \mathrm{NT}-3$ group was significantly greater than the saline group 30 and $40 \mathrm{~min}$ after injection. There were five to eight animals per group. In $A,{ }^{*} p<0.05$, significant difference from the saline group on day 18; Fisher's LSD. In $B, D,{ }^{*} p<0.05$, significant difference from saline at that time point; Fisher's LSD.

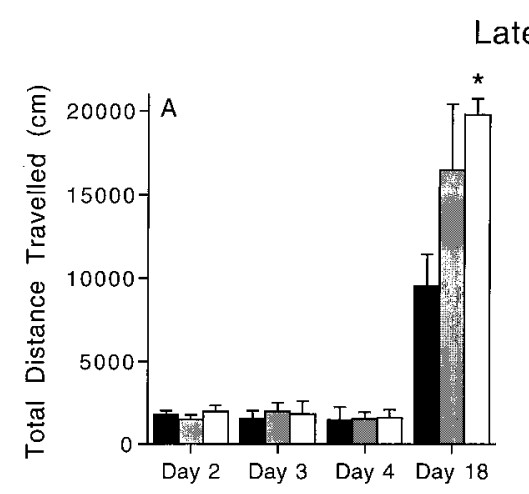

Late Withdrawal
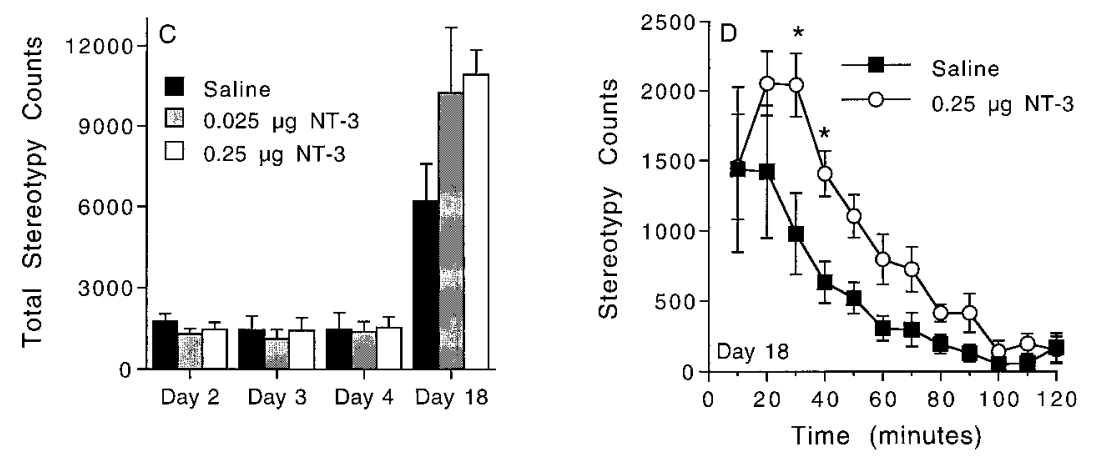

Repeated microinjections of BDNF into the VTA result in sensitization to the behavioral effects of BDNF but have no influence on the behavioral response to a challenge injection of cocaine after $14 \mathrm{~d}$ of withdrawal

The data summarized in Figure $2 A$ indicate that the distance travelled after BDNF was significantly increased after two to three repeated microinjections of $0.25 \mu \mathrm{g}$ of $\mathrm{BDNF}$ into the VTA. These data were analyzed with separate one-way ANOVAs on each treatment day. These analyses showed significant main effects of drug treatment on day $3\left(F_{(2,14)}=3.94 ; p<0.044\right)$ and day $4\left(F_{(2,14)}=5.38 ; p<0.019\right)$. Pairwise comparisons (Fisher's LSD) revealed significant differences between the saline and $0.25 \mu \mathrm{g}$ of BDNF groups on days 3 and 4 . The time course of day 4 data (Fig. $2 B$ ) was analyzed with a mixed factors ANOVA (repeated measure over time). This analysis revealed significant main effects of drug $\left(F_{(1,110)}=4.82 ; p<0.05\right)$ and time $\left(F_{(11,110)}=5.48 ; p<0.0001\right)$. Pairwise comparisons (Fisher's LSD) revealed a significant difference between the BDNF and saline groups at the $110 \mathrm{~min}$ time point.

The stereotypy data (Fig. 2C,D) were analyzed using the same statistics as the distance travelled data summarized above. The analysis of the data shown in Figure $2 C$ revealed marginally significant treatment effects on day $3\left(F_{(2,14)}=2.79 ; p<0.095\right)$ and day $4\left(F_{(2,14)}=2.77 ; p<0.097\right)$. Analysis of the time course data from day 4 showed a significant main effect of time $\left(F_{(11,110)}=5.27 ; p<0.0001\right)$. Pairwise comparisons (Fisher's LSD) revealed a significant difference between the BDNF and saline groups at the 110 min time point (Fig. 2D).

\section{Repeated microinjections of NT-3 or BDNF into the VTA have no influence on a challenge injection of cocaine after $1 \mathrm{~d}$ of withdrawal}

The data summarized in Figure 3 indicate that three daily intraVTA microinjections of $0.25 \mu \mathrm{g}$ of NT-3 or BDNF had no influence on the distance travelled or stereotypy counts induced by $15 \mathrm{mg} / \mathrm{kg}$ cocaine after $1 \mathrm{~d}$ of withdrawal. The distance travelled induced by cocaine in the NT-3, BDNF, and saline groups is depicted in Figure $3 A$. These data were analyzed with a mixed factors ANOVA (repeated measures over time); the analysis revealed a significant main effect of time $\left(F_{(11,143)}=8.87 ; p<\right.$ $0.0001)$ with no other significant main effects or interactions. The stereotyped behavior induced by cocaine after repeated microinjections of NT-3, BDNF, or saline is depicted in Figure $3 B$. These data were analyzed with a mixed factors ANOVA (repeated measures over time); the analysis revealed a significant main effect of time $\left(F_{(11,143)}=6.61 ; p<0.0001\right)$ with no other significant main effects or interactions.

\section{Intra-VTA PD98059 blocks the initiation of behavioral sensitization to cocaine}

The data depicted in Figure 4 indicate that intra-VTA administration of PD98059 impairs the development of sensitization to cocaine. The distance travelled data from Figure $4 A$ were analyzed with a mixed factors ANOVA (repeated measures over day). The results of this analysis revealed a significant main effect of day $\left(F_{(3,48)}=4.16 ; p<0.011\right)$. Pairwise comparisons (Fisher's LSD) showed that the distance travelled on day 18 in the vehicle group was significantly greater than the behavioral response in this group on day 2. The time course of the vehicle and $10 \mu \mathrm{M}$ PD98059 data from day 18 (Fig. 4B) were analyzed with a mixed factors ANOVA (repeated measures over day). This analysis showed significant main effects of drug $\left(F_{(1,132)}=4.55 ; p<0.05\right)$ and time $\left(F_{(11,132)}=17.36 ; p<0.0001\right)$, as well as a significant drug $\times$ time interaction $\left(F_{(11,132)}=2.74 ; p<0.032\right)$. Pairwise comparisons (Fisher's LSD) indicated a significant difference between the vehicle and $10 \mu \mathrm{M}$ PD98059 groups at the $10 \mathrm{~min}$ time point.

The stereotypy data (Fig. $4 C, D$ ) were analyzed using the same statistics as the distance travelled data summarized above. The 


\section{Late Withdrawal}
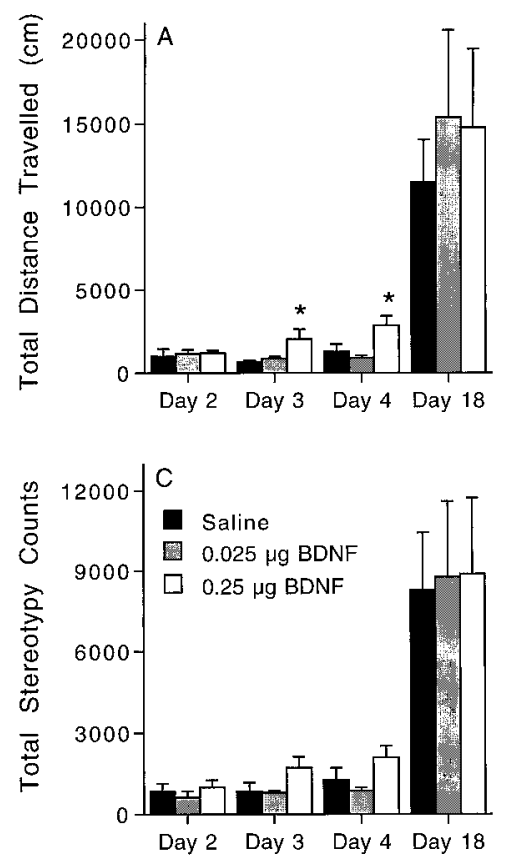
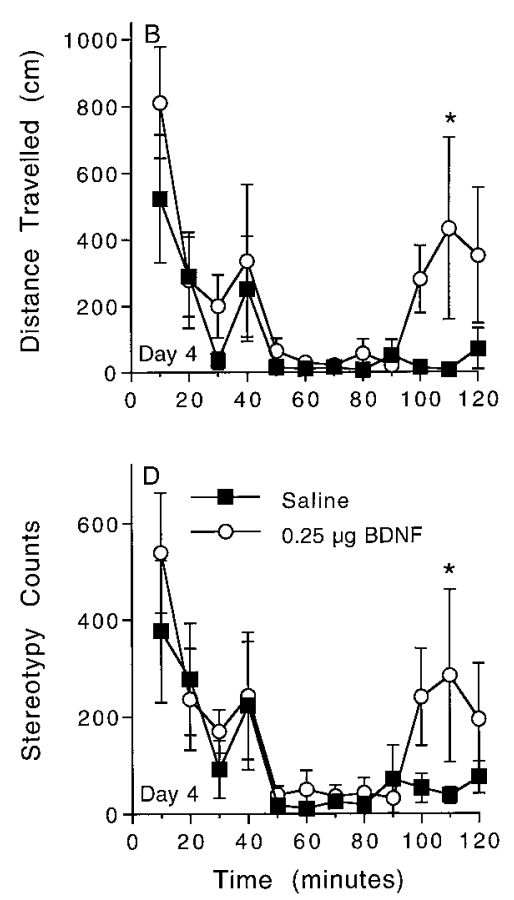

Figure 2. Repeated microinjections of BDNF into the VTA result in sensitization to the behavioral effects of BDNF but have no influence on the behavioral response to cocaine after $14 \mathrm{~d}$ of withdrawal. On days $2-4$, the animals were microinjected with sterile saline or BDNF $(0.025$ or $0.25 \mu \mathrm{g} / 0.5 \mu \mathrm{l}$ per side). After a 2 week withdrawal period (i.e., on day 18), all animals were injected with cocaine $(15 \mathrm{mg} / \mathrm{kg}$, i.p.). $A$, The total distance travelled (in centimeters) recorded over the $120 \mathrm{~min}$ period after the intra-VTA microinjection or the systemic injection of cocaine. Note that the behavioral effect of $0.25 \mu \mathrm{g}$ of BDNF was significantly greater than the saline group on days 3 and 4 . $B$, Time course of the distance travelled in the $0.25 \mu \mathrm{g}$ of BDNF and saline groups from day 4 in $A$. The data are presented as the 120 min behavioral response (distance travelled) divided into $10 \mathrm{~min}$ blocks. Note that the behavioral effect of $0.25 \mu \mathrm{g}$ of BDNF on day 4 was significantly greater than the saline group $110 \mathrm{~min}$ after the microinjection. $C$, The stereotypy counts recorded over the $120 \mathrm{~min}$ period after the intra-VTA microinjection or the systemic injection of cocaine. Note that the behavioral effect of $0.25 \mu \mathrm{g}$ of BDNF on days 3 and 4 was substantially greater than the corresponding saline group. $D$, Time course of the stereotypy counts in the $0.25 \mu \mathrm{g}$ of BDNF and saline groups from day 4 in $C$. The data are presented as the 120 min behavioral response (stereotypy counts) divided into 10 min blocks. Note that the behavioral effect of $0.25 \mu \mathrm{g}$ of BDNF on day 4 was significantly greater than the saline group $110 \mathrm{~min}$ after the microinjection. There were five to six animals per group. In $A,{ }^{*} p<0.05$, significant difference from the saline group on days 3 and 4; Fisher's LSD. In $B, D$, ${ }^{*} p<0.05$, significant difference from saline at that time point; Fisher's LSD. analysis of the data from Figure $3 C$ revealed a significant main effect of day $\left(F_{(3,48)}=4.78 ; p<0.005\right)$. Pairwise comparisons indicated that the stereotypy counts on day 18 in the vehicle group were significantly greater than the behavioral response in this group on day 2. The analysis of the time course data from Figure $3 D$ showed significant main effects of drug $\left(F_{(1,132)}=5.81\right.$; $p<0.033)$ and time $\left(F_{(11,132)}=12.79 ; p<0.0001\right)$, as well as a significant drug $\times$ time interaction $\left(F_{(11,132)}=1.99 ; p<0.034\right)$. Subsequent pairwise comparisons (Fisher's LSD) indicated a significant difference between the vehicle and $10 \mu \mathrm{M}$ PD98059 groups at the $10 \mathrm{~min}$ time point. The vehicle control group consisted of animals that were microinjected with either sterile saline $(n=5)$ or $100 \%$ DMSO $(n=2)$. Preliminary experiments indicated that there was no difference between the cocaineinduced behavioral hyperactivity measured after the intra-VTA microinjection of saline or DMSO.

The location of the microinjection cannulas from the experiments depicted in Figures 1-4, as well as the NT-3 substantia nigra experiment, are depicted in Figure 5. Some of the VTA cannulas were located on the border between the VTA and the medial substantia nigra, the ventral medial lemniscus, and the ventral red nucleus. Of the 100 animals used in these experiments, 24 were excluded from the data analyses because of faulty probe placements.

\section{Effect of acute or repeated cocaine on BDNF and NT-3 mRNA levels in the VTA}

The data depicted in Figure 6 show that an acute cocaine injection resulted in a significant increase in the mRNA levels for NT-3, but not BDNF, in the VTA. Repeated treatment with cocaine, in contrast, did not influence the basal or cocainestimulated increase in NT-3 mRNA levels in the VTA. In other words, tolerance to the acute cocaine-induced increase in NT-3 mRNA levels was observed after repeated cocaine injections. Neither acute nor repeated cocaine administration influenced
BDNF mRNA levels in the VTA. The data from Figure 6 were analyzed with separate one-way ANOVAs. Analysis of the BDNF mRNA data summarized in Figure $6 A$ showed no significant main effect of treatment $\left(F_{(6,64)}=0.34 ; p<0.9131\right)$. The analysis of the NT-3 mRNA data shown in Figure $6 B$ revealed a significant main effect of treatment $\left(F_{(6,64)}=4.18 ; p<0.0013\right)$. Pairwise comparisons (Fisher's LSD) indicated a significant difference between the cocaine $4 \mathrm{hr}$ group and saline. The saline group was comprised of animals that were killed 2, 4, 6, or $24 \mathrm{hr}$ after an acute injection of saline, as well as animals that were injected on 8 consecutive days with saline and were killed $4 \mathrm{hr}$ after the last injection.

\section{Effect of acute or repeated cocaine on the mRNA for BDNF or NT-3 in the substantia nigra}

The data depicted in Figure 7 indicate that neither acute nor repeated cocaine injections altered BDNF mRNA levels in the substantia nigra. Acute injection of cocaine also had no effect on NT-3 mRNA levels in this structure. Repeated injections of cocaine resulted in a relatively minor decrease in nigral NT-3 mRNA levels. These data were analyzed with separate one-way ANOVAs. The analysis of the BDNF data from Figure $7 A$ revealed no significant main effect of treatment $\left(F_{(6,62)}=1.41\right.$; $p<0.224)$. The results of the ANOVA performed on the NT-3 mRNA data depicted in Figure $7 B$ revealed a marginally significant main effect of treatment $\left(F_{(6,66)}=2.32 ; p<0.043\right)$. Pairwise comparisons (Fisher's LSD) demonstrated a significant difference between the repeated cocaine with a cocaine challenge injection group and the saline group.

\section{Effect of acute cocaine on the mRNA for BDNF and NT-3 in the hippocampus}

The data summarized in Figure 8 demonstrate that an acute injection of cocaine did not influence the mRNA for either BDNF or NT-3 in the hippocampus. These data were analyzed 


\section{Early Withdrawal}
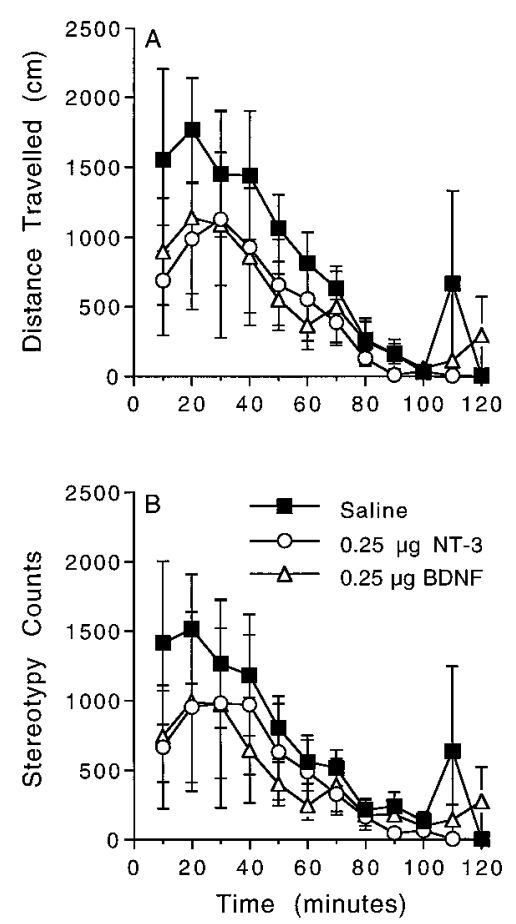

Figure 3. Repeated microinjections of BDNF or NT-3 into the VTA have no influence on the behavioral effects of cocaine after $1 \mathrm{~d}$ of withdrawal. On days $2-4$, the animals were microinjected with sterile saline, NT-3, or BDNF $(0.25 \mu \mathrm{g} / 0.5 \mu \mathrm{l}$ per side $)$. After a $1 \mathrm{~d}$ withdrawal period (i.e., on day 5), all animals were injected with cocaine $(15 \mathrm{mg} / \mathrm{kg}$, i.p.). $A$, The time course of the distance travelled (in centimeters) recorded over the $120 \mathrm{~min}$ period after the systemic injection of cocaine on day 5. Note that there was no significant difference among the NT-3, BDNF, and saline groups at any time point. $B$, The time course of the stereotypy counts recorded over the $120 \mathrm{~min}$ period after the systemic injection of cocaine on day 5 . Note that there was no significant difference among the NT-3, BDNF, and saline groups at any time point. There were five to six animals per group.

with separate one-way ANOVAs. The analysis of the BDNF mRNA data from Figure $8 A$ showed no significant main effect of treatment $\left(F_{(4,31)}=0.964 ; p<0.441\right)$. Likewise, there was no significant effect of treatment for the NT-3 data depicted in Figure $8 B\left(F_{(4,30)}=0.085 ; p<0.9865\right)$.

\section{DISCUSSION}

Our results indicate that repeated microinjections of NT-3 into the VTA sensitize the mesolimbic dopamine system to a subsequent challenge injection of cocaine. An acute injection of cocaine also resulted in a substantial increase in NT-3 mRNA levels in the VTA, which suggests that cocaine increases NT-3 synthesis. Microinjections of the MEK inhibitor PD98059 into the VTA before daily injections of cocaine blocked the initiation of behavioral sensitization. Collectively, these results provide strong evidence that NT-3 and the Ras/MAP kinase signal transduction system play important roles in behavioral sensitization to cocaine. The present data also showed that, whereas repeated intra-VTA BDNF microinjections had no influence on the subsequent behavioral effects of cocaine, BDNF itself produced a progressive augmentation in behavioral activation with repeated administration.

\section{NT-3 and behavioral sensitization to cocaine}

The NT-3 behavioral results suggest that repeated intra-VTA NT-3 mimics the initiation of cocaine behavioral sensitization. Cross-sensitization between NT-3 and cocaine was observed only when a withdrawal period was imposed between the repeated microinjections and a challenge injection of cocaine. This result is similar to previous findings indicating that cocaine-induced behavioral sensitization is more robust when a withdrawal period is used (Kolta et al., 1985; Kalivas and Duffy, 1993a; Paulson and Robinson, 1995). With intracranial drug administration, diff usion of the compound into areas adjacent to the microinjection is a concern. It seems unlikely that an effect of NT-3 in the substantia nigra contributed to the sensitizing effects of intra-VTA NT-3, however, because repeated microinjections of this neurotrophin directly into the substantia nigra had no influence on the subsequent behavioral effects of cocaine.

The present data also indicate that an acute injection of cocaine results in a transient increase in NT-3 synthesis (as reflected by an increase in NT-3 mRNA levels) selectively in the VTA. After eight daily injections of cocaine, tolerance developed to the ability of this drug to increase the mRNA levels for NT-3 in the VTA. It is improbable, therefore, that this increase in NT-3 synthesis is in itself responsible for the expression of behavioral sensitization to cocaine. It is possible, however, that an increase in NT-3 mRNA levels could contribute to the initiation of behavioral sensitization. There are several neurophysiological changes associated with the initiation, although not the expression, of behavioral sensitization. For example, repeated cocaine injections result in a decrease in the inhibitory effects of apomorphine on dopamine neurons in the VTA, an effect that dissipates 1 week after the termination of repeated drug administration (Lee et al., 1988; Henry et al., 1989; Ackerman and White, 1990). The sensitized increase in extracellular dopamine in the VTA of cocainesensitized rats also is observed only during the first few days of withdrawal (Kalivas and Duffy, 1993b). Together, these results indicate that daily psychostimulant injections produce transient alterations in dopamine autoreceptor sensitivity and somatodendritic dopamine release. Results such as these form the basis of a distinction between the neurophysiological mechanisms underlying the transient initiation and long-term expression of behavioral sensitization (Kalivas and Stewart, 1991; Pierce and Kalivas, 1997). It is thought that the neurophysiological processes that contribute to the initiation of behavioral sensitization are necessary to trigger other permanent changes in the mesotelencephalic dopamine system that are directly involved in the long-term maintenance of behavioral sensitization (Kalivas et al., 1993; White et al., 1995). The cocaine-induced increase in NT-3 synthesis in the VTA appears to be another example of a physiological phenomenon that contributes to the initiation rather than the expression of cocaine sensitization.

The main limitation of RT-PCR experiments and of all studies using brain homogenates is the inability to identify the population of cells or terminals in which a change in mRNA levels is expressed. Thus, it is impossible to determine whether the cocaineinduced changes in NT-3 mRNA levels observed in the present experiments occurred exclusively in the dopaminergic cells of the VTA. This limitation will be addressed in future experiments in which in situ hybridization for neurotrophin mRNA coupled with immunohistochemistry for tyrosine hydroxylase will be used. If these experiments confirm that there is a cocaine-induced increase in NT-3 synthesis in dopamine neurons, additional exper- 

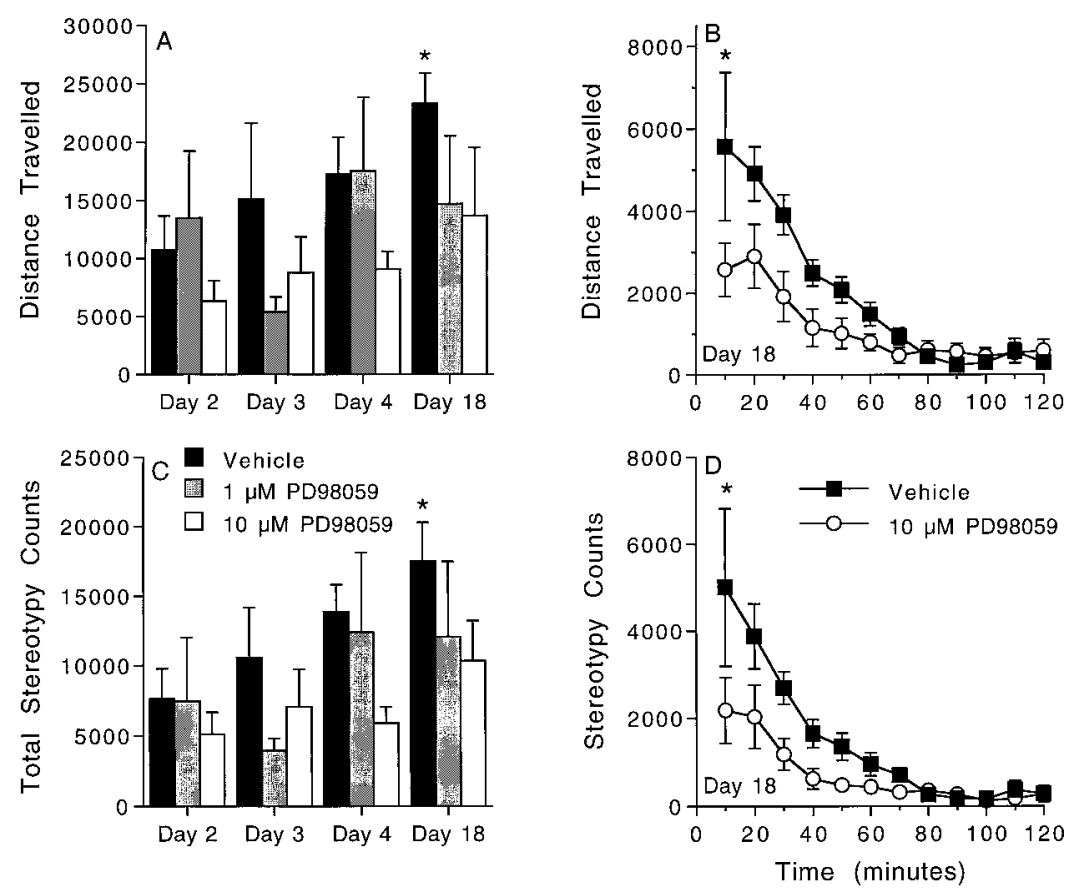
PD98059 groups from day 18 in $C$. The data are presented as the 120 min behavioral response (stereotypy counts) divided into 10 min blocks. Note that the behavioral effect of cocaine on day 18 in the vehicle group was significantly greater than the $10 \mu \mathrm{M}$ PD98059 group 10 min after injection. There were five to seven animals per group. In $A, C,{ }^{*} p<0.05$, significant difference from day 2 within the same group; Fisher's LSD. In $B, D,{ }^{*} p<0.05$, significant difference from $10 \mu \mathrm{M}$ PD98059 at that time point; Fisher's LSD.

iments will be performed to determine the extent to which these changes in mRNA levels are translated into protein that may be secreted into the VTA and/or nucleus accumbens.

Psychostimulant-induced increases in NT-3 synthesis and release could result in structural changes in nuclei associated with the mesolimbic dopamine system. Repeated injections of amphetamine induce relatively long-lasting increases in the density of dendritic spines on the output cells of the nucleus accumbens (Robinson and Kolb, 1997). These structural modifications are similar to anatomical changes observed in the CNS after neurotrophin administration (McAllister et al., 1996; Shimada et al., 1998). Together, these findings suggest that psychostimulantinduced increases in neurotrophin synthesis and release could induce persistent structural modifications in the VTA and/or nucleus accumbens that may contribute to the expression of behavioral sensitization.

\section{Cocaine sensitization and the Ras/MAP kinase signal transduction cascade}

Activation of neurotrophin receptors and the Ras/MAP kinase signal transduction cascade are known to play important roles in neuroplasticity (Orban et al., 1999; Schuman, 1999). The MAP kinases also may contribute to the modifications in the mesolimbic dopamine transmission observed after repeated psychostimulant injections. Consistent with this hypothesis, the present results indicate that intra-VTA administration of an MEK inhibitor blocks the development of behavioral sensitization to cocaine. This result is consistent with recent evidence indicating that repeated cocaine induces an increase in ERK activity in the VTA (Berhow et al., 1996). An enduring increase in the activity of the MAP kinases in the mesolimbic dopamine system would enhance the activity of tyrosine hydroxylase, the rate-limiting enzyme in catecholamine synthesis (Haycock et al., 1992; Seger and Krebs, 1995). Interestingly, increases in tyrosine hydroxylase activity and
Figure 4. Intra-VTA microinjection of the MEK inhibitor PD98059 blocks the initiation of behavioral sensitization to cocaine. On days $2-4$, the animals were microinjected with vehicle (sterile saline or DMSO) or PD98059 $(1$ or $10 \mu \mathrm{M} / 0.5$ $\mu \mathrm{l}$ per side) into the VTA 20 min before a systemic injection of cocaine $(15 \mathrm{mg} / \mathrm{kg}$, i.p.). After a 2 week withdrawal period (i.e., on day 18), all animals were injected with cocaine (15 $\mathrm{mg} / \mathrm{kg}$, i.p.) in the absence of a microinjection. $A$, The total distance travelled (in centimeters) recorded over the $120 \mathrm{~min}$ period after the systemic injection of cocaine. Note that the behavioral effect of cocaine was significantly greater in the vehicle group on day 18 relative to day 2 , whereas there was no significant difference between the behavioral responses to cocaine on days 2 and 18 in the PD98059 groups. In other words, behavioral sensitization to cocaine was observed in the vehicle group but not in the PD98059 groups. Neither dose of PD98059, however, influenced the acute behavioral response to cocaine. $B$, Time course of the distance travelled after cocaine in the $10 \mu \mathrm{M}$ PD98059 and vehicle groups from day 18 in $A$. The data are presented as the 120 min behavioral response (distance travelled) divided into $10 \mathrm{~min}$ blocks. Note that the behavioral effect of cocaine on day 18 in the vehicle group was significantly greater than the $10 \mu \mathrm{M}$ PD98059 group 10 min after injection. $C$, The stereotypy counts recorded over the $120 \mathrm{~min}$ period after the systemic injection of cocaine. Note that the behavioral effect of cocaine was significantly greater in the vehicle group on day 18 relative to the vehicle group on day $1 . D$, Time course of the stereotypy counts after cocaine in the vehicle and $10 \mu \mathrm{M}$

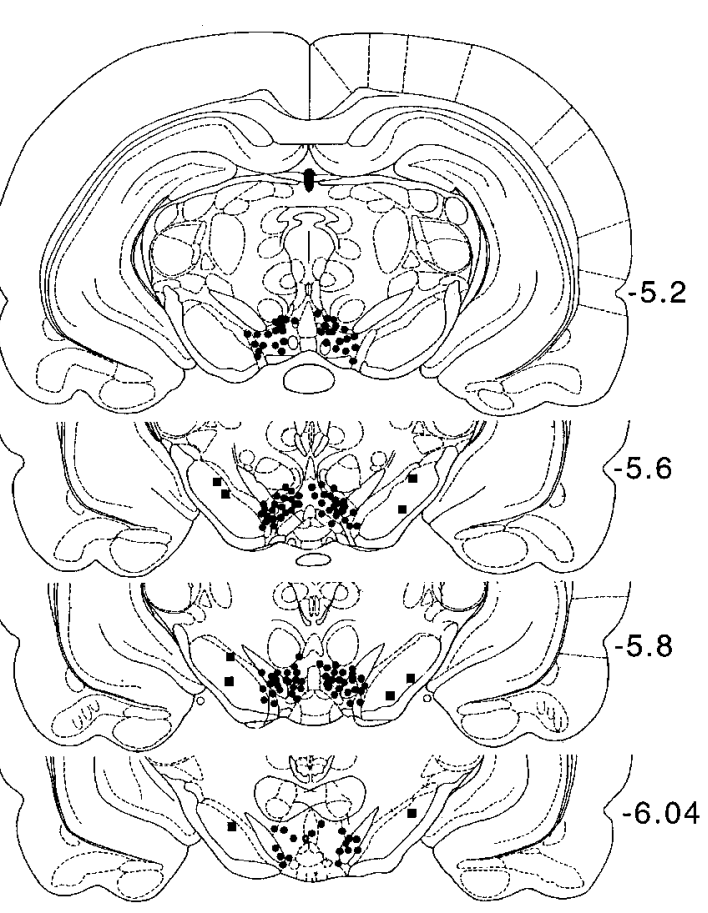

Figure 5. Location of microinjection sites from the behavioral data summarized in Figures 1-4. The circles represent the microinjections targeted at the VTA. Note that some of the cannula tips were located on the border between the VTA and the medial substantia nigra, the ventral medial lemniscus, and the ventral red nucleus. The squares depict the location of the cannula tips in the lateral substantia nigra. The schematic brain sections are from the atlas of Paxinos and Watson (1997). The numbers indicate millimeters from bregma. 


\section{Ventral Tegmental Area}
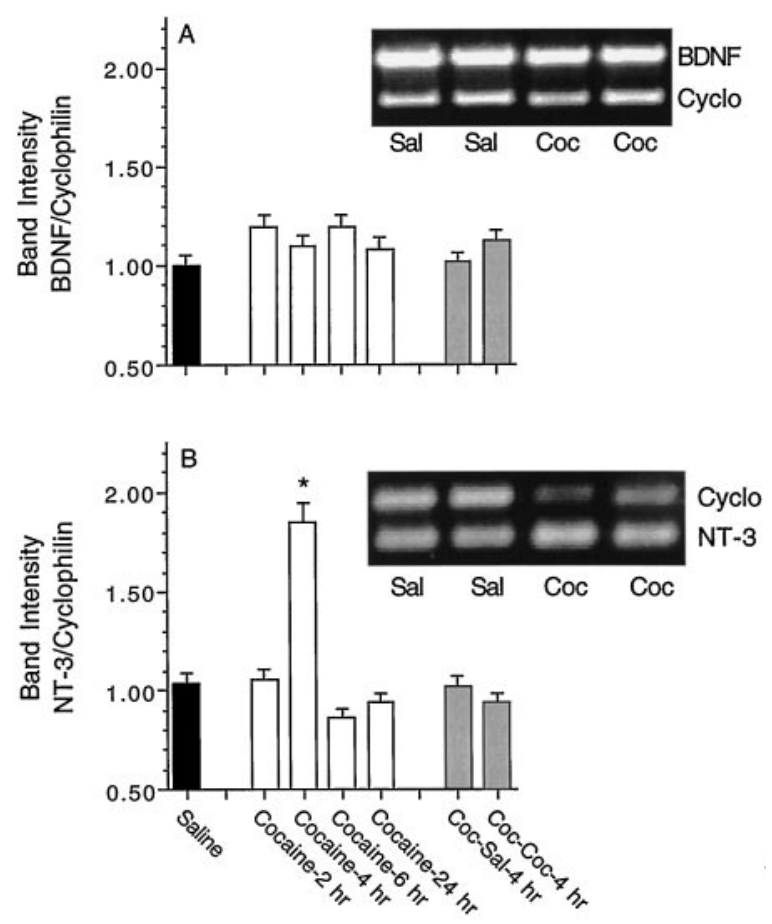

Figure 6. Effect of acute or repeated cocaine or saline injections on BDNF and NT-3 mRNA levels in the VTA. mRNA levels were assessed $2,4,6$, or $24 \mathrm{hr}$ after an acute injection of saline or $30 \mathrm{mg} / \mathrm{kg}$ cocaine. In addition, BDNF and NT-3 mRNA levels were assessed after seven daily injections of $30 \mathrm{mg} / \mathrm{kg}$ cocaine. On the eighth day, half of the animals were injected with saline, and the other half were injected with $30 \mathrm{mg} / \mathrm{kg}$ cocaine. Thus, Coc-Sal denotes seven daily injections of cocaine (30 $\mathrm{mg} / \mathrm{kg}$ ), followed by a challenge injection of saline, and Coc-Coc signifies seven daily injections of cocaine $(30 \mathrm{mg} / \mathrm{kg})$, followed by a challenge injection of this same dose of cocaine. The animals in the Coc-Sal and Coc-Coc groups were killed $4 \mathrm{hr}$ after the saline or cocaine challenge injection on day 8. All injections were given intraperitoneally. The data are presented as a ratio of the density of the BDNF or NT-3 mRNA band relative to the control cyclophilin mRNA band; the data are expressed as percent of the mean of the saline control group. There were 6-14 animals per group, with the exception of the saline group. The saline group was comprised of 21 animals; 14 were injected with saline acutely, and seven received repeated, daily saline injections. $A$, Effect of acute or repeated cocaine on BDNF mRNA levels in the VTA. Inset, Representative cyclophilin (Cyclo) and BDNF bands obtained via RT-PCR from the VTA of two rats from the saline ( $\mathrm{Sal}$ ) and two rats from the cocaine-4 $\mathrm{hr}$ $(C O C)$ groups. B, Effect of acute or repeated cocaine on NT-3 mRNA levels in the VTA. Note the increase in NT-3 mRNA in the VTA $4 \mathrm{hr}$ after an acute injection of cocaine. Note also that tolerance to this effect developed after eight daily injections of cocaine. Inset, Representative cyclophilin (Cyclo) and NT-3 bands obtained via RT-PCR from the VTA of rats in the saline $(\mathrm{Sal})$ and cocaine- $4 \mathrm{hr}(\mathrm{Coc})$ groups. ${ }^{*} p<0.05$, significant difference from saline; Fisher's LSD.

mRNA levels in the VTA have been observed to persist for at least $15 \mathrm{~d}$ after the cessation of repeated cocaine (BeitnerJohnson and Nestler, 1991; Vrana et al., 1993; Masserano et al., 1996; but see Sorg et al., 1993) or methamphetamine (Zhang and Angulo, 1996) injections. This enduring increase in dopamine synthesis may, in turn, contribute to the sensitized increase in accumbal dopamine release that is associated with the expression of behavioral sensitization to cocaine (Kolta et al., 1985; Robinson et al., 1988; Akimoto et al., 1989; Parsons and Justice, 1993; Wolf et al., 1993; Pierce and Kalivas, 1996).

In the current experiments NT-3, but not BDNF, cross-
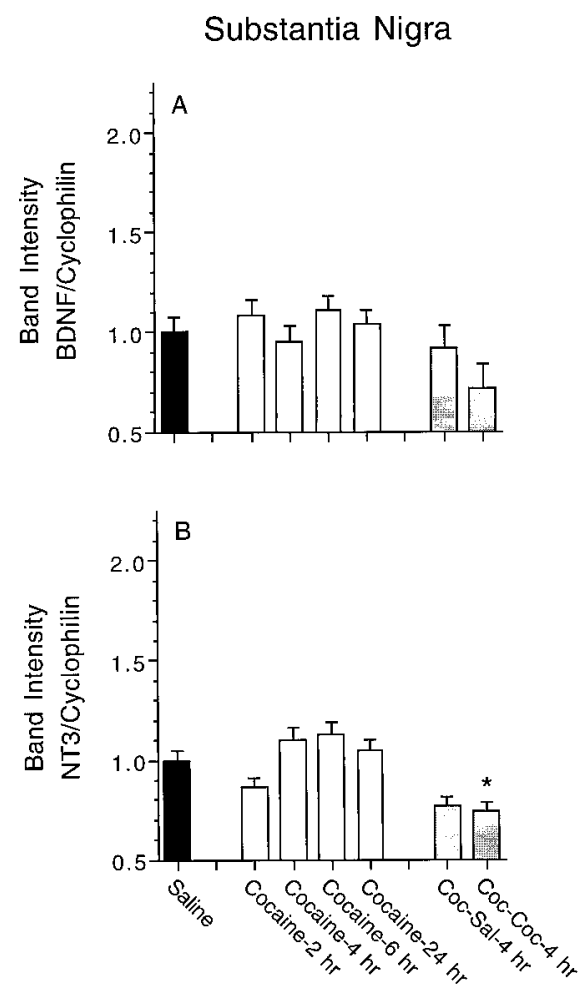

Figure 7. Effect of acute or repeated cocaine or saline injections on BDNF and NT-3 mRNA in the substantia nigra. mRNA levels were assessed 2, 4, 6, or $24 \mathrm{hr}$ after an acute injection of saline or $30 \mathrm{mg} / \mathrm{kg}$ cocaine. In addition, BDNF and NT-3 mRNA levels were assessed after seven daily injections of $30 \mathrm{mg} / \mathrm{kg}$ cocaine. On the eighth day, half of the animals were injected with saline, and the other half were injected with 30 $\mathrm{mg} / \mathrm{kg}$ cocaine. Thus, Coc-Sal denotes seven daily injections of cocaine $(30 \mathrm{mg} / \mathrm{kg})$, followed by a challenge injection of saline, and Coc-Coc signifies seven daily injections of cocaine $(30 \mathrm{mg} / \mathrm{kg})$, followed by a challenge injection of this same dose of cocaine. The animals in the Coc-Sal and Coc-Coc groups were killed $4 \mathrm{hr}$ after the saline or cocaine challenge injection on day 8 . All injections were given intraperitoneally. The data are presented as a ratio of the density of the BDNF or NT-3 mRNA band relative to the control cyclophilin mRNA band; the data are expressed as percent of the mean of the saline control group. There were 6-11 animals per group. $A$, Effect of acute or repeated cocaine on BDNF mRNA levels in the substantia nigra. $B$, Effect of acute or repeated cocaine on NT-3 mRNA levels in the substantia nigra. Note that there was a slight decrease in the mRNA for NT-3 in the Coc-Coc-4 hr group. ${ }^{*} p<$ 0.05 , significant difference from saline; Fisher's LSD.

sensitized with cocaine. This result may reflect a greater influence of NT-3 on the Ras/MAP kinase signal transduction cascade. This conclusion is supported by recent results indicating that NT-3 receptors primarily activate the MAP kinase system, whereas some effects of BDNF require the activation of both the MAP and phosphatidylinositol-3 kinases (Takei et al., 1999). Moreover, in adult rat dopamine neurons, BDNF prevents axotomy-induced cell death to a much greater extent than NT-3, although NT-3 has a greater influence on tyrosine hydroxylase activity (Hagg, 1998), which is stimulated by the MAP kinases (Haycock et al., 1992; Seger and Krebs, 1995).

The Ras/MAP kinase signal transduction cascade may be stimulated by means other than the activation of Trk receptors. Notably, NMDA-mediated calcium currents, by activating calcium/calmodulin-dependent (CaM) kinases, stimulate the MAP kinases (Farnsworth et al., 1995; Xia et al., 1996; Vincent et al., 1998; Egea et al., 1999). This finding is particularly relevant 
Hippocampus
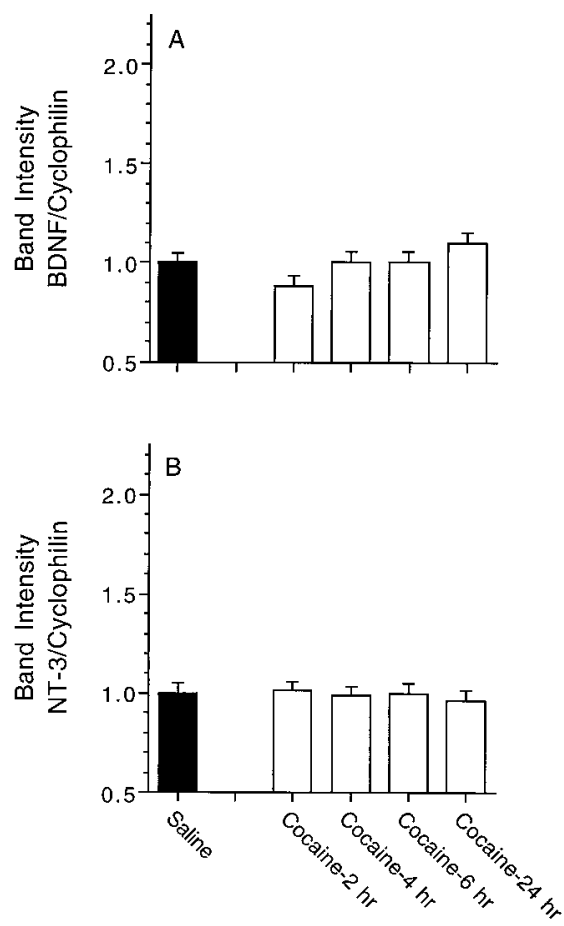

Figure 8. Effect of an acute cocaine or saline injection on BDNF and NT-3 mRNA levels in the hippocampus. mRNA levels were assessed 2, 4, 6 , or $24 \mathrm{hr}$ after injection (saline or $30 \mathrm{mg} / \mathrm{kg}$ cocaine). The data are presented as a ratio of the density of the BDNF or NT-3 mRNA band relative to the control cyclophilin mRNA band; the data are expressed as percent of the mean of the saline control group. There were 5-11 animals per group. $A$, Effect of an acute cocaine injection on BDNF mRNA levels in the hippocampus. $B$, Effect of an acute cocaine injection on NT-3 mRNA levels in the hippocampus.

in the context of behavioral sensitization because the initiation of this process is blocked by NMDA antagonists (Karler et al., 1989; Wolf and Khansa, 1991; Kalivas and Alesdatter, 1993; Stewart and Druhan, 1993). In addition, administration of a CaM kinase inhibitor directly into the shell of the nucleus accumbens impaired the expression of behavioral sensitization (Pierce et al., 1998). These data indicate that calcium-mediated transduction pathways, including those stimulated by NMDA receptors, play a critical role in behavioral sensitization. Because there are important interactions between the CaM kinase and MAP kinase transduction systems, it is possible that NMDA receptors contribute to behavioral sensitization by activating both of these kinases.

\section{Sensitization to the behavioral effects of intra-VTA BDNF}

Previous results indicate that chronic unilateral infusion of BDNF into the substantia nigra results in an increase in exploratory behavior (Martin-Iverson and Altar, 1996), as well as an enhancement in amphetamine-induced contralateral rotations (Martin-Iverson et al., 1994; Martin-Iverson and Altar, 1996). Similarly, intra-VTA BDNF increases spontaneous activity and potentiates cocaine-induced behavioral hyperactivity (Horger et al., 1999). In these studies, BDNF was being infused into the ventral midbrain via an osmotic minipump when the psychostimulant challenge injection was made; it is possible, therefore, that the potentiation of psychostimulant-induced behavioral activation resulted from the additive behavioral effects of BDNF and amphetamine or cocaine. The current findings demonstrate that repeated microinjections of BDNF into the VTA resulted in a progressive augmentation in the behavioral response to BDNF but have no influence on the behavioral hyperactivity produced by a subsequent cocaine injection in the absence of BDNF. Collectively, these results indicate that, although BDNF influences the behavioral output of the mesolimbic dopamine system, BDNF-induced plasticity does not appear to contribute to psychostimulant sensitization. Indeed, chronic intra-VTA infusions of BDNF may actually impair the development of behavioral sensitization to $15 \mathrm{mg} / \mathrm{kg}$ cocaine (Horger et al., 1999).

\section{Conclusions}

Our results indicate that three once daily administrations of either NT-3 or BDNF promote plasticity in the mesolimbic dopamine system. However, the behavioral consequences of intra-VTA administration of NT-3 and BDNF differ. NT-3, apparently acting through the Ras/MAP kinase signaling cascade, plays an important role in the initiation of behavioral sensitization to cocaine. This result provides additional information on the plasticity induced by cocaine in the CNS that may contribute to our understanding of the rudimentary mechanisms underlying the drug craving associated with psychostimulant withdrawal (Robinson and Berridge, 1993). In contrast, whereas BDNF does not appear to play a role in behavioral sensitization, repeated microinjections of this neurotrophin into the VTA resulted in a progressive increase in behavioral activation. This result adds to a growing literature indicating that the influence of BDNF on dopamine neurons may assist in the treatment of motor disorders, such as Parkinson's disease (Hyman et al., 1991; Beck et al., 1992; Spina et al., 1992; Benisty et al., 1998).

\section{REFERENCES}

Ackerman JM, White FJ (1990) A10 somatodendritic dopamine autoreceptor sensitivity following withdrawal from repeated cocaine treatment. Neurosci Lett 117:181-187.

Akimoto K, Hamamura T, Otsuki S (1989) Subchronic cocaine treatment enhances cocaine-induced dopamine efflux, studies by in vivo intracerebral dialysis. Brain Res 490:339-344.

Beck KD, Knusel B, Winslow JW, Rosenthal A, Burton K, Nikolics K, Hefti F (1992) Pretreatment of dopaminergic neurons in culture with brain-derived neurotrophic factor attenuates toxicity of 1-methyl-4phenylpyridinium. Neurodegeneration 1:27-36.

Beitner-Johnson D, Nestler EJ (1991) Morphine and cocaine exert common chronic actions on tyrosine hydroxylase in dopaminergic brain reward regions. J Neurochem 57:344-347.

Benisty S, Boissiere F, Faucheux B, Agid Y, Hirsch EC (1998) trkB messenger mRNA expression in normal human brain and in the substantia nigra of parkinsonian patients: an in situ hybridization study. Neuroscience 86:813-826.

Berhow MT, Russell DS, Terwilliger RZ, Beitner-Johnson D, Self DW, Lindsay RM, Nestler EJ (1995) Influence of neurotrophic factors on morphine- and cocaine-induced biochemical changes in the mesolimbic dopamine system. Neuroscience 68:969-979.

Berhow MT, Hiroi N, Nestler EJ (1996) Regulation of ERK (extracellular signal regulated kinase), part of the neurotrophin signal transduction cascade, in the rat mesolimbic dopamine system by chronic exposure to morphine or cocaine. J Neurosci 16:4707-4715.

Bjijou Y, Stinus L, Le Moal M, Cador M (1996) Evidence for selective involvement of dopamine D1 receptors of the ventral tegmental area in the behavioral sensitization induced by intra-ventral tegmental area injections of D-amphetamine. J Pharmacol Exp Ther 277:1177-1187.

Bothwell M (1995) Functional interactions of neurotrophins and neurotrophin receptors. Annu Rev Neurosci 18:223-253.

Cathala G, Savouret JF, Mendez B, West BL, Karin M, Martial JA, Baxter JD (1983) A method for isolation of intact, translationally active ribonucleic acid. DNA 2:329-335.

Ceccatelli S, Ernfors P, Villar MJ, Persson H, Hokfelt T (1991) Expanded distribution of mRNA for nerve growth factor, brain-derived 
neurotrophic factor, and neurotrophin 3 in the rat brain after colchicine treatment. Proc Natl Acad Sci USA 88:10352-10356.

Conner JM, Lauterborn JC, Yan Q, Gall CM, Varon S (1997) Distribution of brain-derived neurotrophic factor (BDNF) protein and mRNA in the normal adult rat CNS: evidence for anterograde axonal transport. J Neurosci 17:2295-2313.

Davies AM (1994) The role of neurotrophins in the developing nervous system. J Neurobiol 25:1334-1348.

Dudley DT, Pang L, Decker SJ, Bridges AJ, Saltiel AR (1995) A synthetic inhibitor of the mitogen-activated protein kinase cascade. Proc Natl Acad Sci USA 92:7686-7689.

Egea J, Espinet C, Comella JX (1999) Calcium influx activates extracellular-regulated kinase/mitogen-activated protein kinase pathway through a calmodulin-sensitive mechanism in PC12 cells. J Biol Chem 274:75-85.

Ernfors P, Wetmore C, Olson L, Persson H (1990) Identification of cells in rat brain and peripheral tissues expressing mRNA for members of the nerve growth factor family. Neuron 5:511-526.

Farnsworth CL, Freshney NW, Rosen LB, Ghosh A, Greenberg ME, Feig LA (1995) Calcium activation of Ras mediated by neuronal exchange factor Ras-GRF. Nature 376:524-527.

Gall CM, Gold SJ, Isackson PJ, Seroogy KB (1992) Brain-derived neurotrophic factor and neurotrophin 3 mRNAs are expressed in ventral midbrain regions containing dopaminergic neurons. Mol Cell Neurosci 3:56-63.

Hagg T (1998) Neurotrophins prevent death and differentially affect tyrosine hydroxylase of adult rat nigrostriatal neurons in vivo. Exp Neurol 149:183-192.

Haycock JW, Ahn NG, Cobb MH, Krebs EG (1992) ERK1 and ERK2, two microtubule-associated protein 2 kinases, mediate the phosphorylation of tyrosine hydroxylase at serine-31 in situ. Proc Natl Acad Sci USA 89:2365-2369.

Henry DJ, Greene MA, White FJ (1989) Electrophysiological effects of cocaine in the mesoaccumbens dopamine system: repeated administration. J Pharmacol Exp Ther 251:833-839.

Horger BA, Iyasere CA, Berhow MT, Messer CJ, Nestler EJ, Taylor JR (1999) Enhancement of locomotor activity and conditioned reward to cocaine by brain-derived neurotrophic factor. J Neurosci 19:4110-4122.

Hyman C, Hofer M, Barde Y-A, Juhasz M, Yancopoulos GD, Squinto SP, Lindsay RM (1991) BDNF is a neurotrophic factor for dopaminergic neurons of the substantia nigra. Nature 350:230-232.

Kalivas PW, Alesdatter JE (1993) Involvement of NMDA receptor stimulation in the VTA and amygdala in behavioral sensitization to cocaine. J Pharmacol Exp Ther 267:486-495.

Kalivas PW, Duffy P (1993a) Time course of extracellular dopamine and behavioral sensitization to cocaine. I. Dopamine axon terminals. J Neurosci 13:266-275.

Kalivas PW, Duffy P (1993b) Time course of extracellular dopamine and behavioral sensitization to cocaine. II. Dopamine perikarya. J Neurosci 13:276-284.

Kalivas PW, Stewart J (1991) Dopamine transmission in the initiation and expression of drug- and stress-induced sensitization of motor activity. Brain Res Rev 16:223-244.

Kalivas PW, Hooks MS, Sorg B (1993) The pharmacology and neural circuitry of sensitization to psychostimulants. Behav Pharmacol 4:315-334.

Karler R, Calder LD, Chaudhry IA, Turkanis SA (1989) Blockade of "reverse tolerance" to cocaine and amphetamine by MK-801. Life Sci 45:599-606.

Knusel B, Winslow JW, Rosenthal A, Burton LE, Seid DP, Nikolics K, Hefti F (1991) Promotion of central cholinergic and dopaminergic neuron differentiation by brain-derived neurotrophic factor but not neurotrophin 3. Proc Natl Acad Sci USA 88:961-965.

Kolta MG, Shreve P, De Souza V, Uretsky NJ (1985) Time course of the development of the enhanced behavioral and biochemical responses to amphetamine after pretreatment with amphetamine. Neuropharmacology 24:823-829.

Lauterborn JC, Isackson PJ, Gall CM (1991) Nerve growth factor messenger RNA-containing cells are distributed within regions of cholinergic neurons in the rat basal forebrain. J Comp Neurol 306:439-446.

Lauterborn JC, Bizon JL, Tran TM, Gall CM (1995) NGF mRNA is expressed by GABAergic but not cholinergic neurons in the rat basal forebrain. J Comp Neurol 360:454-462.

Lee TH, Ellinwood Jr EH, Nishita JK (1988) Dopamine receptor sen- sitivity changes with chronic stimulants. Ann NY Acad Sci 537:324-329.

Lewin GR, Barde Y-A (1996) Physiology of the neurotrophins. Annu Rev Neurosci 19:289-317.

Martin-Iverson MT, Altar CA (1996) Spontaneous behaviors of rats are differentially affected by substantia nigra infusions of brain-derived neurotrophic factor and neurotrophin-3. Eur J Neurosci 8:1696-1706.

Martin-Iverson MT, Todd KG, Altar CA (1994) Brain-derived neurotrophic factor and neurotrophin-3 activate striatal dopamine and serotonin metabolism and related behaviors: interactions with amphetamine. J Neurosci 14:1262-1270.

Masserano JM, Baker I, Natsukari N, Wyatt RJ (1996) Chronic cocaine administration increases tyrosine hydroxylase activity in the ventral tegmental area through glutaminergic- and dopaminergic $\mathrm{D}_{2}$-receptor mechanisms. Neurosci Lett 217:73-76.

McAllister AK, Katz LC, Lo DC (1996) Neurotrophin regulation of cortical dendritic growth requires activity. Neuron 17:1057-1064.

Numan S, Seroogy KB (1999) Expression of trkB and trkC mRNAs by adult midbrain dopamine neurons: a double-label in situ hybridization study. J Comp Neurol 403:295-308.

Orban PC, Chapman PF, Brambilla R (1999) Is the Ras-MAPK signalling pathway necessary for long-term memory formation? Trends Neurosci 22:38-44.

Parsons LH, Justice Jr JB (1993) Serotonin and dopamine sensitization in the nucleus accumbens, ventral tegmental area and dorsal raphe nucleus following repeated cocaine administration. $\mathrm{J}$ Neurochem 61:1611-1619.

Paulson PE, Robinson TE (1995) Amphetamine-induced timedependent sensitization of dopamine neurotransmission in the dorsal and ventral striatum: a microdialysis study in behaving rats. Synapse 19:56-65

Paxinos G, Watson C (1997) The rat brain in stereotoxic coordinates. San Diego: Academic.

Perugini M, Vezina P (1994) Amphetamine administered to the ventral tegmental area sensitizes rats to the locomotor effects of nucleus accumbens amphetamine. J Pharmacol Exp Ther 270:690-696.

Pierce RC, Kalivas PW (1996) Amphetamine produces sensitized locomotion and dopamine release preferentially in the nucleus accumbens shell of rats administered repeated cocaine. J Pharmacol Exp Ther 275:1019-1029.

Pierce RC, Kalivas PW (1997) A circuitry model of the expression of behavioral sensitization to amphetamine-like psychostimulants. Brain Res Rev 25:192-216.

Pierce RC, Kalivas PW (1998) Locomotor behavior. In: Current protocols in neuroscience (Crawley J, ed). New York: Wiley.

Pierce RC, Born B, Adams M, Kalivas PW (1996) Repeated intraventral tegmental area administration of SKF-38393 induces behavioral and neurochemical sensitization to a subsequent cocaine challenge. J Pharmacol Exp Ther 278:384-392.

Pierce RC, Quick EA, Reeder DC, Morgan ZR, Kalivas PW (1998) Calcium-mediated second messengers modulate the expression of behavioral sensitization to cocaine. J Pharmacol Exp Ther 286:1171-1176

Robinson TE, Berridge KC (1993) The neural basis of drug craving: An incentive-sensitization theory of addiction. Brain Res Rev 18:247-291.

Robinson TE, Kolb B (1997) Persistent structural modifications in nucleus accumbens and prefrontal cortex neurons produced by previous experience with amphetamine. J Neurosci 17:8491-8497.

Robinson TE, Jurson PA, Bennett JA, Bentgen KM (1988) Persistent sensitization of dopamine neurotransmission in ventral striatum (nucleus accumbens) produced by previous experience with $(+)$-amphetamine: a microdialysis study in freely moving rats. Brain Res 462:211-222.

Schuman E (1999) Neurotrophin regulation of synaptic transmission. Curr Opin Neurobiol 9:105-109.

Seger R, Krebs EG (1995) The MAPK signaling cascade. FASEB J 9:726-735.

Seroogy KB, Lundgren KH, Tran TMD, Guthrie KM, Isackson PJ, Gall CM (1994) Dopaminergic neurons in rat ventral midbrain express brain-derived neurotrophic factor and neurotrophin-3 mRNAs. J Comp Neurol 342:321-334.

Shimada A, Mason CA, Morrison ME (1998) TrkB signaling modulates spine density and morphology independent of dendrite structure in cultured neonatal Purkinje cells. J Neurosci 18:8559-8570.

Sorg BA, Chen S-Y, Kalivas PW (1993) Time course of tyrosine hydrox- 
ylase expression following behavioral sensitization to cocaine. J Pharmacol Exp Ther 266:424-430.

Spillantini MG, Aloe L, Alleva E, de Simone R, Goedert M, LeviMontalcini R (1989) Nerve growth factor mRNA and protein increase in hypothalamus in a mouse model of aggression. Proc Natl Acad Sci USA 86:8555-8559.

Spina MB, Squinto SP, Miller J, Lindsay RM, Hyman C (1992) Brainderived neurotrophic factor protects dopamine neurons against 6-hydroxydopamine and $\mathrm{N}$-methyl-4-phenylpyridinium ion toxicity: involvement of the glutathione system. J Neurochem 59:99-106.

Stewart J, Druhan JP (1993) The development of both conditioning and sensitization of the behavioral activating effects of amphetamine is blocked by the noncompetitive NMDA receptor antagonist, MK-801. Psychopharmacology 110:125-132.

Takei N, Tanaka O, Endo Y, Lindholm D, Hatanaka H (1999) BDNF and NT-3 but not CNTF counteract the $\mathrm{Ca}^{2+}$ ionophore-induced apoptosis of cultured cortical neurons: involvement of dual pathways. Neuropharmacology 38:283-288.

Thoenen H (1995) Neurotrophins and neuronal plasticity. Science 270:593-598.

Timmusk T, Belluardo N, Metsis M, Persson H (1993) Widespread and developmentally regulated expression of neurotrophin-4 mRNA in rat brain and peripheral tissues. Eur J Neurosci 5:605-613.

Vezina $\mathrm{P}$ (1996) $\mathrm{D}_{1}$ dopamine receptor activation is necessary for the induction of sensitization by amphetamine in the ventral tegmental area. J Neurosci 16:2411-2420.
Vincent SR, Sebben M, Dumuis A, Bockaert J (1998) Neurotransmitter regulation of MAP kinase signalling in striatal neurons in primary culture. Synapse 29:29-36.

Vrana SL, Vrana KE, Koves TR, Smith JE, Dworkin SI (1993) Chronic cocaine administration increases CNS tyrosine hydroxylase enzyme activity and mRNA levels and tryptophan hydroxylase enzyme activity levels. J Neurochem 61:2262-2268.

White FJ, Xiu Y-H, Henry DJ, Zhang X-F (1995) Neurophysiological alterations in the mesocorticolimbic dopamine system during repeated cocaine administration. In: The neurobiology of cocaine addiction (Hammer R, ed), pp 99-120. Boca Raton, FL: CRC.

Wolf ME, Khansa MR (1991) Repeated administration of MK-801 produces sensitization to its own locomotor stimulant effects but blocks sensitization to amphetamine. Brain Res 562:164-168.

Wolf ME, White FJ, Nassar R, Brooderson RJ, Khansa MR (1993) Differential development of autoreceptor subsensitivity and enhanced dopamine release during amphetamine sensitization. J Pharmacol Exp Ther 264:249-255.

Xia Z, Dudek H, Miranti CK, Greenberg ME (1996) Calcium influx via the NMDA receptor induces immediate early gene transcription by a MAP kinase/ERK-dependent mechanism. J Neurosci 16:5425-5436.

Zhang Y, Angulo JA (1996) Contrasting effects of repeated treatment vs. withdrawal of methamphetamine on tyrosine hydroxylase messenger RNA levels in the ventral tegmental area and substantia nigra zona compacta of the rat brain. Synapse 24:218-223. 